RASĀYAN J. Chem.

Vol. 12 | No. 4 |2218 - 2226| October - December | 2019 ISSN: 0974-1496 | e-ISSN: 0976-0083 | CODEN: RJCABP

\title{
THE EFFECT OF ALCCOFINE IN COCONUT SHELL CONCRETE AND EXAMINING BOND THROUGH INVERTED METALLURGIC MICROSCOPE
}

\author{
V. R. Prasath Kumar and K.Gunasekaran \\ Department of Civil Engineering, SRM Institute of Science and Technology, \\ Kancheepuram Dt.-603203,Tamil Nadu, India \\ *E-mail prasathv@srmist.edu.in
}

\begin{abstract}
The use of natural resources in concrete production makes environmental fret. One of the possible solutions to save the natural resources is to use different generated solid waste. Coconut shell (CS) is one of the agriculture waste which is been tried recently as coarse aggregate in the production of concrete. The emission of carbon dioxide $\left(\mathrm{CO}_{2}\right)$ due to cement production is also one of the causes of global warming. Hence, in this study alccofine is used as partial replacement for cement. The alccofine was replaced from 5 to $25 \%$ in the increment of $5 \%$ both in coconut shell and conventional concrete for the target strength of M20. Compressive strength of all these mixes was conducted at $3,7,28,56,90,180$ and 365 day. It was observed that $10 \%$ replacement of alccofine gives higher strength compared to another percentage level. However, 20\% replacement had also achieved the targeted compressive strength, which confirms the better percentage level to replace cement and witness the optimized percentage level. The other properties say, split tensile, flexural and impact strength were done using the optimized level for 3, 7 and 28 days of curing period. The inverted metallurgical microscope (IMM) was used to inspect the interfacial transition zone between aggregates and cement mortar, which confirms and the bonding layer is inversely proportional to its age.
\end{abstract}

Keywords: Alccofine, Coconut Shell concrete, Optimization, Properties, Inverted Metallurgic Microscope.

(C) RASĀYAN. All rights reserved

\section{INTRODUCTION}

Today the construction industry is one of the growing industries that have an excessive influence on the economy of any nation. Any part of infrastructure or real estate initiated around us is undertaken by segments under construction industry. The economy producing industry should also consider the generation of waste and utilizing the natural resources that lead to a great impact on environmental complications. Therefore there is a need to replace an alternate material for natural coarse aggregate. Scoria was used to produce lightweight concrete by choosing aggregate passing through $10 \mathrm{~mm}$ and retaining in $5 \mathrm{~mm}$ and the compressive strength of $10 \mathrm{Mpa}$ was obtained with density of $100 \mathrm{~kg} / \mathrm{m}^{3}{ }^{1}{ }^{1}$ The perlite, scoria, polystyrene, recycled aggregate and rubber granules were few lightweight aggregates which were used to produce lightweight self-compacting concrete. ${ }^{2,3}$ The carpet waste is adjusted to create another kind of lightweight with low mass thickness is used for application in concrete materials. ${ }^{4}$ The locally accessible agro-waste materials, such as oil palm shell and oil palm boiler clinker from the oil palm industries was utilized as coarse aggregate in the manufacturing of lightweight concrete. ${ }^{5}$ Coconut shell is being hard and not easily degradable can be a potential material that can be used as a coarse aggregate in concrete. the author had done enough research work on coconut shell concrete comparing with conventional concrete. ${ }^{6-12}$ A various durability test was performed on coconut shell concrete, which indicated better results compared to conventional concrete. ${ }^{13}$ The pull out test was carried out to prove the bond strength properties of reinforced coconut shell concrete. ${ }^{14}$ The coconut shell concrete yields higher strength by replacing cement with GGBS comparing to controlled concrete as well as the micro structural studies were been carried out for CSC incorporating with GGBS. ${ }^{15}$ Alccofine is one of the new generation

Rasayan J. Chem., 12(4), 2218-2226(2019)

http://dx.doi.org/10.31788/RJC.2019.1245231

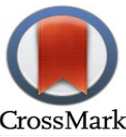


RASĀYAN J. Chem.

Vol. 12 | No. 4 |2218 - 2226| October - December | 2019

microfine material used for producing high strength and workability. ${ }^{16}$ Geopolymer concrete was made by enacting pond fly powder with $14 \mathrm{M} \mathrm{NaOH}$ and sodium silicate arrangements. Alccofine powder was included in geopolymerization process, which expanded the pressure quality likewise as silica fume, and also alccofine is incorporated to find the properties of fly ash-based geopolymer concrete at ambient temperature. ${ }^{17,18}$ Since the alccofine is an ultra-fine material helps in achieving self-compacting concrete, thus eliminates noise due to vibration, reduces the crack and microstructural defects and provides high stability during transport and placement. ${ }^{19}$ Alccofine is used in replacing cement and reducing the water even up to $70 \%$, incorporating fly ash, and increases the compressive strength, flexural strength and improves the workability and concrete properties. ${ }^{20,21}$ High strength concrete was obtained by replacing cement with alccofine, silica fume and GGBS. The compressive strength of $43.2 \mathrm{~N} / \mathrm{mm}^{2}$ with density of $1970 \mathrm{~kg} / \mathrm{m}^{3}$ is achieved with a combination of GGBS and alccofine at $50 \%+15 \%{ }^{22}$ The worn image wear pattern of alloy and composite sample was analyzed through inverted metallurgical microscope to find its hardness. ${ }^{23}$ Microstructure of the manufactured composite example was watched using IMM and result indicated uniform distribution of support particles in the matrix. ${ }^{24}$

\section{MATERIALS}

\section{EXPERIMENTAL}

\section{Coconut Shell}

The major ingredient used for the work is coconut shell, coarse aggregate, river sand and alccofine. The coconut shells are collected from the Vellore district in Tamil Nadu. The collected CS are well-seasoned and broken into aggregates in the coconut shell crusher which is been installed in SRM Institute of science and technology. The CS is soaked in water and made to saturated surface dry (SSD) condition at room temperature before they are used for casting. This is done because the CS in purely dry state has the capacity to absorb the water in concrete, to avoid this action; they are made to an SSD so that their capacity to absorb the water during concrete mixing can be prevented. The CS that is passed through 12 $\mathrm{mm}$ and retained in $4.75 \mathrm{~mm}$ sieve is used as a coarse aggregate to prepare the CSC. The physical and mechanical properties of CS are given in Table-1.

\section{Aggregates}

The fine aggregate (River sand from Palaru River) and coarse aggregates were collected through local vendors, the fine aggregate was well sieved to remove the waste and maintained under the size of 4.75 $\mathrm{mm}$. The coarse aggregate is passed through $12 \mathrm{~mm}$ and retained in $10 \mathrm{~mm}$ sieve and was taken to cast controlled concrete. The selection and test on aggregates were done as per IS383:1970. ${ }^{28}$ The physical and mechanical properties of coarse and fine aggregate are given in Table-1.

\section{Alccofine}

Alccofine is a supplementary cementation material was manufactured from slag of high glass content which used in preparation of concrete by replacing cement to a certain extent. Alccofine enhances the performance of concrete due to its optimized practical size distribution. It is a mineral additive has a specific surface around $12000 \mathrm{~cm}^{2} / \mathrm{gm}$, which proves to be an ultra-fine material. The properties of alccofine and cement are given in Table-2.

Table-1: Physical and Mechanical Properties of Aggregates

\begin{tabular}{|c|c|c|c|c|}
\hline \multicolumn{2}{|c|}{ Properties } & Coconut Shell & Coarse Aggregate & $\begin{array}{l}\text { Fine Aggregate } \\
\text { (River Sand) }\end{array}$ \\
\hline \multicolumn{2}{|c|}{ Size $(\mathrm{mm})$} & $4-8$ & 10 to 12.5 & Less than 4.75 \\
\hline \multicolumn{2}{|c|}{ Moisture Content (\%) } & 4.5 & - & - \\
\hline \multicolumn{2}{|c|}{ Water Absorption (\%) } & 22 & 0.3 & - \\
\hline \multicolumn{2}{|c|}{ Specific Gravity } & 1.15 & 2.84 & 2.5 \\
\hline \multicolumn{2}{|c|}{ Impact Value (\%) } & 8.2 & 12.5 & - \\
\hline \multicolumn{2}{|c|}{ Crushing Value (\%) } & 2.5 & 6.25 & - \\
\hline \multicolumn{2}{|c|}{ Abrasion Value (\%) } & 1.6 & 1.9 & - \\
\hline \multirow{2}{*}{$\begin{array}{c}\text { Bulk Density in } \\
\left(\mathrm{kg} / \mathrm{m}^{3}\right)\end{array}$} & Compacted & 650 & 1620 & 580 \\
\hline & Loose & 550 & 1450 & - \\
\hline
\end{tabular}


RASĀYAN J. Chem.

Vol. 12 | No. 4 |2218 - 2226| October - December | 2019

\begin{tabular}{r|c|c|c|c}
\hline \multirow{2}{*}{ Voids (\%) } & Compacted & 38.12 & 41.57 & - \\
\cline { 2 - 5 } & Loose & 47.65 & 48.66 & - \\
\hline \multicolumn{2}{l}{ Fineness Modulus } & 6.3 & 6.84 & 2.54 \\
\hline
\end{tabular}

Table-2: Physical and Chemical Properties of Binding Materials

\begin{tabular}{c|c|c}
\hline \multirow{2}{*}{ Mineral Composition } & \multicolumn{2}{|c}{ Binding Materials (\%) } \\
\cline { 2 - 3 } & OPC & Alccofine \\
\hline $\mathrm{CaO}$ & 63 & $31-33$ \\
\hline $\mathrm{Al}_{2} \mathrm{O}_{3}$ & 1.33 & $23-25$ \\
\hline $\mathrm{SiO}_{2}$ & 21.6 & $33-35$ \\
\hline $\mathrm{MgO}$ & 0.7 & - \\
\hline $\mathrm{Fe}_{2} \mathrm{O}_{3}$ & 3.7 & - \\
\hline $\mathrm{Na}_{2} \mathrm{O}$ & 0.4 & - \\
\hline $\mathrm{SO}_{3}$ & 0.88 & 2.9 \\
\hline Specific Gravity & 3.15 & 12000 \\
\hline Specific Surface $\left(\mathrm{cm}^{2} / \mathrm{gm}\right)$ & 2250 & Pale white \\
\hline Colour & Grey & - \\
\hline Fineness $(\%)$ & 5 &
\end{tabular}

\section{Mix Proportion}

IS 456:2000 32 is generally used for the mix design in India. But IS codes aren't sufficient enough for an accurate mix design for lightweight concrete. So generally trial and error methods are adopted for getting the better mix design which has been already proved by K.Gunasekaran. ${ }^{6}$ The mix design of 1:2.22:3.66:0.55 was adopted for CC and 1:1.47:0.65:0.42 was adopted for CSC. The natural crushed stones are used as coarse aggregates in CC, whereas saturated surface dried CS have used as coarse aggregates in CSC. Table-4 indicates the material quantity for both the type of concrete for $1 \mathrm{~m}^{3}$. Since this study is about comparing the replacement of cement with alccofine in both the concrete, hence the coarse aggregate, fine aggregate and water content for both conventional and coconut shell concrete remains the same for all the replacement of cement with alccofine. The replacement of cement by alccofine is done on weight basis. The weight of coarse aggregate and fine aggregate is $1171 \mathrm{~kg} / \mathrm{m}^{3}$ and $710 \mathrm{~kg} / \mathrm{m}^{3}$ for CC, and for CSC it is $332 \mathrm{~kg} / \mathrm{m}^{3}$ and $750 \mathrm{~kg} / \mathrm{m}^{3}$ in weight for CS aggregate and fine aggregate. The water content is $176 \mathrm{~kg} / \mathrm{m}^{3}$ and $214.2 \mathrm{~kg} / \mathrm{m}^{3}$ for CC and CSC. The mixed number from AC 1 to AC 6 denotes the various percentage of cement and alccofine for CC and ACS 7 to ACS 12 denotes the same for CSC. The material proportion for $1 \mathrm{~m}^{3}$ of concrete is shown in the below Table-3.

Table-3: Material Quantity of Conventional and Coconut Shell Concrete

\begin{tabular}{|c|c|c|c|c|c|c|}
\hline \multirow{3}{*}{$\begin{array}{c}\text { Cement }+ \\
\text { Alccofine } \\
(\%)\end{array}$} & \multicolumn{6}{|c|}{ Material Proportion of for $1 \mathrm{~m}^{3}$} \\
\hline & \multicolumn{3}{|c|}{$\mathrm{CC}$} & \multicolumn{3}{|c|}{$\mathrm{CSC}$} \\
\hline & Mix No & $\begin{array}{c}\text { Cement } \\
(\mathrm{kg})\end{array}$ & $\begin{array}{c}\text { Alccofine } \\
(\mathrm{kg})\end{array}$ & Mix No & $\begin{array}{c}\text { Cement } \\
(\mathrm{kg})\end{array}$ & $\begin{array}{l}\text { Alccofine } \\
(\mathrm{kg})\end{array}$ \\
\hline $100+0$ & $\mathrm{AC} 1$ & 320 & 0 & ACS 7 & 510 & 0 \\
\hline $95+5$ & $\mathrm{AC} 2$ & 304 & 16 & ACS 8 & 484.5 & 25.5 \\
\hline $90+10$ & $\mathrm{AC} 3$ & 288 & 32 & ACS 9 & 459 & 51 \\
\hline $85+15$ & $\mathrm{AC} 4$ & 272 & 48 & ACS 10 & 433.5 & 76.5 \\
\hline $80+20$ & $\mathrm{AC} 5$ & 256 & 64 & ACS 11 & 408 & 102 \\
\hline $75+25$ & $\mathrm{AC} 6$ & 240 & 80 & $\mathrm{ACS} 12$ & 382.5 & 127.5 \\
\hline
\end{tabular}

\section{Specimen Preparation}

The compressive strength was determined by casting a cube of size $100 \mathrm{~mm} \times 100 \mathrm{~mm} \times 100 \mathrm{~mm}$. For the entire test minimum three samples were tested and the average is given as the result. The density of CC is between 2500 to $2600 \mathrm{~kg} / \mathrm{m}^{3}$, and for CSC it is between 1930 to $2000 \mathrm{~kg} / \mathrm{m}^{3}$. Slump value was in the range between $5 \mathrm{~mm}$ to $31 \mathrm{~mm}$ for $\mathrm{CC}$ and $10 \mathrm{~mm}$ to $38 \mathrm{~mm}$ for coconut shell concrete for different mix proportions. Since the workability was low, table vibrator was used to compact the specimens for all mixes. The split tensile strength was determined by casting the cylinder of size $100 \mathrm{~mm}$ diameter and 200 
RASĀYAN J. Chem.

Vol. 12 | No. 4 |2218 - 2226| October - December | 2019

$\mathrm{mm}$ in height for both $\mathrm{CC}$ and CSC. The flexural strength test was determined of casting and testing the beam of size $500 \mathrm{~mm} \times 100 \mathrm{~mm} \times 100 \mathrm{~mm}$ for both the concrete. Similarly impact test was carried out by casting disc of size $150 \mathrm{~mm} \times 63.5 \mathrm{~mm}$ and the test was conducted according to ACI committee 544.1R82. The split tensile, flexural and impact tests are conducted for the optimized percentage of alccofine. The compressive strength and flexural strength tests are conducted by confirming to IS 516-1959. ${ }^{29}$, and split tensile strength test was done according to IS 5816:1999. ${ }^{30}$

\section{RESULTS AND DISCUSSION}

Various tests were conducted to make a comparison between the CC and the CS concrete with alccofine content. The test results are discussed in the figures.

\section{Compressive Strength}

Both CC and CS concrete specimens are cast by replacing cement with alccofine at $0,5,10,15,20$ \& $25 \%$ and the testing was done with curing days of $3,7,28,56,90,180$ and 360 days respectively. Figure 1(a) shows the average compressive strength value of CC from 3 to 365 days and 1(b) shows the same for 3 to 50 days. Similarly 2(a) and 2(b) represent the average compressive strength of CSC. Figures- 1(a), 1(b) and 2(a), 2(b) are united under Fig.-1 and 2.

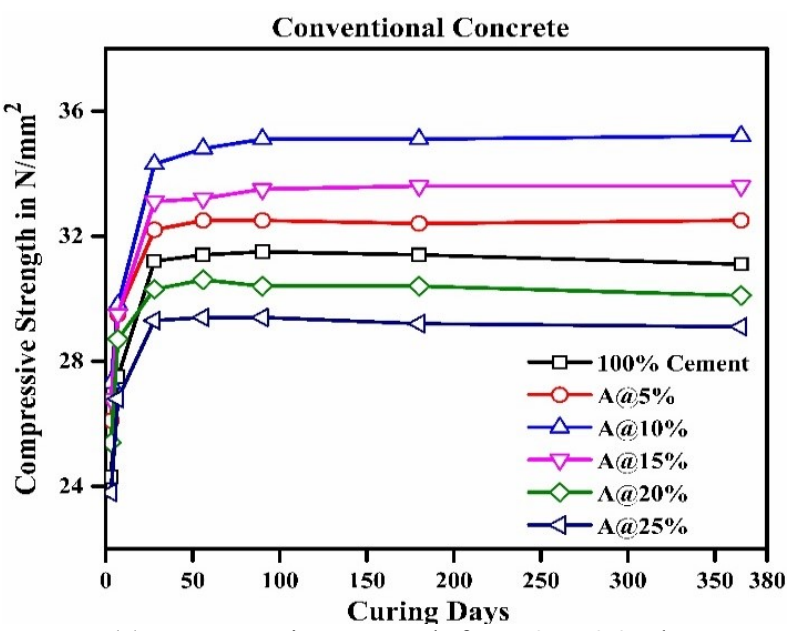

(a) Compressive strength from 3 to 365 days

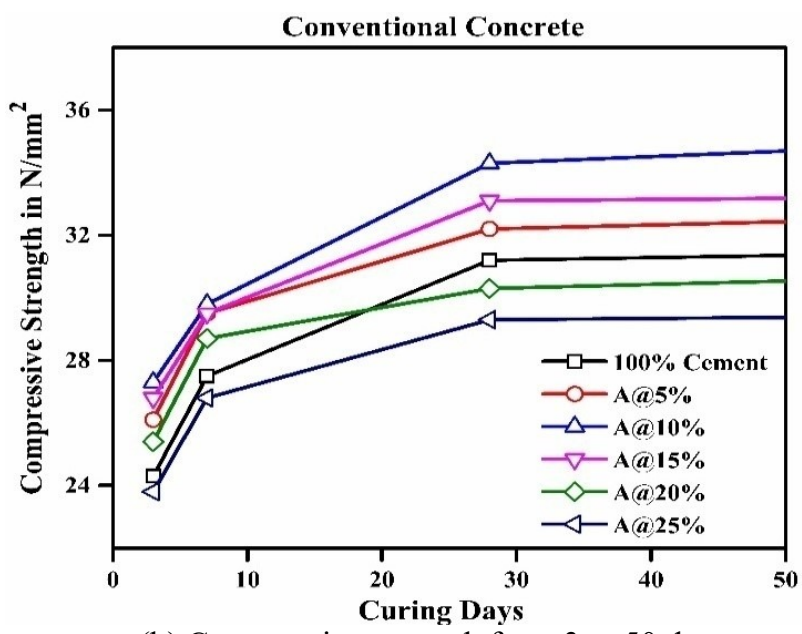

(b) Compressive strength from 3 to 50 days

Fig.-1: Compressive Strength of CC

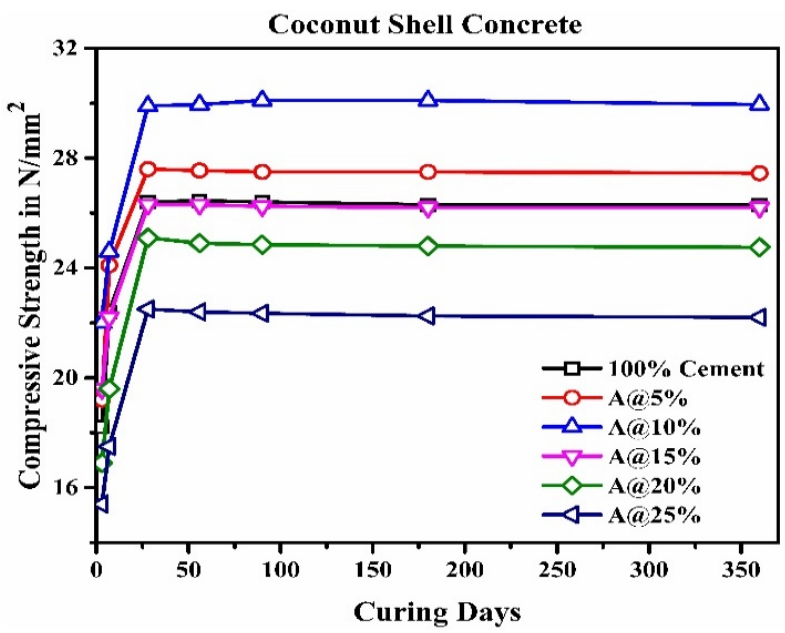

(a) Compressive strength from 3 to 365 days

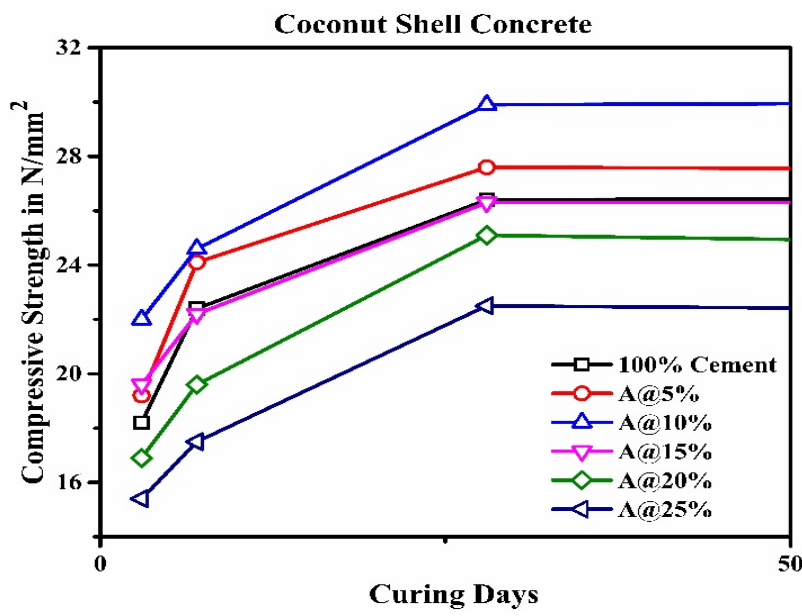

(b) Compressive strength from 3 to 50 days

Fig.-2: Compressive Strength of CSC

The compressive strength of both the concrete on replacement with alccofine was compared with $100 \%$ cement. The results were found to be increasing from 5 to $10 \%$ in both the concrete in comparing with 2221 
RASĀYAN J. Chem.

Vol. 12 | No. 4 |2218 - 2226| October - December | 2019

$100 \%$ cement for first 28 days, and later on there is very mild increment in the strength from 56 to 365 days. The increase in percentage of alccofine level from 5 to $10 \%$, found increase in compressive strength, and further increase of alccofine from 15 to $25 \%$, decreases the compressive strength value in both CC and CSC. The $28^{\text {th }}$ day compressive strength of CSC at $20 \%$ and $25 \%$ replacement of cement with alccofine is $25.1 \mathrm{~N} / \mathrm{mm}^{2}$ and $22.5 \mathrm{~N} / \mathrm{mm}^{2}$, hence the replacement of alccofine at $20 \%$ has met the targeted mean strength of M20, and this shows the optimum replacement of cement with alccofine is at $20 \%$. At the same time, the value of CC for the same replacement has slightly higher value than $100 \%$ cement concrete.

\section{Ultrasonic Pulse Velocity}

The strength and standards of concrete are assessed by an in-situ, non-destructive UPV test. The test is done by transmitting ultrasonic waves through concrete and measuring time taken between transmission $\&$ collection of waves through the structures. Higher the velocity of waves within structure a good quality material can be obtained. The standards of concrete such as the fractures, internal cracks, strength, porosity, air entrapped can be inferred from conducting this test. The test can be conducted in order to assess the potency of the crack outfit. Ultrasonic testing is conducted according to IS $13311-1992 .{ }^{31}$ The test is conducted for both conventional and coconut shell concrete specimens for the $10 \%$ replaced cement with alccofine. The average pulse velocity for CC was found to be $5.523,5333$ and $5.627 \mathrm{~m} / \mathrm{sec}$ for 3,7 and $28^{\text {th }}$ day curing period, which states the concrete is excellent in quality. The average pulse velocity for coconut shell concrete was found as $4.304,4.429$ and $4.484 \mathrm{~m} / \mathrm{sec}$ for the curing period of 3 , 7 and 28, which stated the quality of coconut shell CSC is good. The UPV value was more or less in the same range up to 365 days of curing for both the concrete and it proved to be excellent quality for CC and good quality for CSC. The grading of concrete quality with respect to velocity is given in the below Table-4.

Table-4: Velocity Criteria for Grading of Concrete Quality

\begin{tabular}{c|c}
\hline Pulse Velocity $[\mathrm{m} / \mathrm{sec}]$ & Grading of Concrete Quality \\
\hline Above 4500 & Excellent \\
\hline 3500 to 4500 & Good \\
\hline 3000 to 3500 & Medium \\
\hline Below 3000 & Doubtful \\
\hline
\end{tabular}

\section{Flexural Strength}

The casting and testing of the beam to find the flexural strength are done at $20 \%$ (optimum percentage) replacement of cement with alccofine. Table- 5 shows the test results of both the concrete at $28^{\text {th }}$ day.

Table-5: Flexural Strength of CC and CSC at $28^{\text {th }}$ Day

\begin{tabular}{c|c|c|c|c}
\hline \multirow{2}{*}{ Test } & \multicolumn{2}{|c|}{ CC in N/mm } & \multicolumn{2}{c}{ CSC in N/mm $\mathrm{m}^{2}$} \\
\cline { 2 - 4 } & AC1 & AC5 & ACS7 & ACS11 \\
\hline Flexural Strength & 4.33 & 4.20 & 3.54 & 3.40 \\
\hline $\begin{array}{c}\text { As per IS 456:2000 } \\
(0.7 \sqrt{ } \text { fck })\end{array}$ & 3.90 & 3.85 & 3.59 & 3.50 \\
\hline Compressive Strength & 31.20 & 30.30 & 26.4 & 25.10 \\
\hline
\end{tabular}

The flexural strength of CC with $100 \%$ cement is $11.03 \%$ above the theoretic strength. When $20 \%$ of cement is replaced with alccofine the flexural strength increased by $9.09 \%$ against theoretical strength. In coconut shell concrete the flexural strength with $100 \%$ cement is $1.39 \%$ less than theoretical strength when $20 \%$ of cement is replaced with alccofine the strength decreases by $2.86 \%$ against theoretical value. It can be concluded that by replacing $20 \%$ of cement with alccofine in CSC the flexural strength is lesser than its $\mathrm{CC}$ by $1.47 \%$. Hence this concrete can be used where primary requirement of flexural strength is not necessary.

\section{Split Tensile Strength}

The casting and testing of a cylinder of size $100 \mathrm{~mm}$ in diameter and $200 \mathrm{~mm}$ in height are done to find the split tensile strength for optimum percent level of alccofine and $100 \%$ cement. The $28^{\text {th }}$ test results are shown in table 6, for both CC and CSC. 
RASĀYAN J. Chem.

Vol. 12 | No. 4 |2218 - 2226| October - December | 2019

Table-6: Split Tensile Strength of CC and CSC at $28^{\text {th }}$ Day

\begin{tabular}{c|c|c|c|c}
\hline \multirow{2}{*}{ Test } & \multicolumn{2}{|c|}{$\mathrm{CC}$ in $\mathrm{N} / \mathrm{mm}^{2}$} & \multicolumn{2}{c}{ CSC in N/mm ${ }^{2}$} \\
\cline { 2 - 5 } & $\mathrm{AC} 1$ & $\mathrm{AC5}$ & $\mathrm{ACS} 7$ & $\mathrm{ACS} 11$ \\
\hline Split Tensile Strength & 3.3 & 3.15 & 2.67 & 2.52 \\
\hline Compressive Strength & 31.2 & 30.3 & 26.4 & 25.1 \\
\hline
\end{tabular}

The split tensile strength of AC1 and AC5 are $10.57 \%$ and $10.40 \%$ of the compressive strength of respective concrete. The split tensile strength of ACS7 and ACS11 are $10.11 \%$ and $10.03 \%$ of compressive strength of respective concrete. This shows CSC has similar performance that of CC when replaced with alccofine at $20 \%$.

\section{Impact Strength}

The disc of size $150 \mathrm{~mm}$ in diameter and $63.5 \mathrm{~mm}$ in thickness was cast for both CC and CSC. The test was conducted under impact testing machine for 3,7 and $28^{\text {th }}$ day. The casting of specimen was done for the optimum level of alccofine, says at $20 \%$, and compared with $100 \%$ cement for both the concrete. The number of blows was counted until the initial crack was obtained on the specimen, and the blows were further continued till the final crack obtained. Table-7 shows the average impact resistance of $\mathrm{CC}$ and CSC on $28^{\text {th }}$ day. The number of blows took to attain the initial and final crack for CC and CSC at AC1 is $12-20$ and $21-28$, from this study the CC having the compressive strength of $31.2 \mathrm{~N} / \mathrm{mm}^{2}$, has less impact resistance comparing to CSC at $26.4 \mathrm{~N} / \mathrm{mm}^{2}$, this is because of the fiber content present in the CS. The results show the replacement of cement with alccofine has more impact value than at $100 \%$ cement.

\section{Inverted Metallurgical Microscopic Analysis}

The inverted metallurgical microscope (IMM) allows for inspection of the grain size of any materials. It is used in the engineering and manufacturing processes to look for metal fatigue, corrosion, fractures, ruptures and bond width that resulted from stress, cracks of any materials. The sample of CC and CSC were cut into size of $10 \mathrm{~mm} \times 10 \mathrm{~mm}$ and placed in the polisher, where the specimens are initially polished with 300 Grid sandpaper to obtain initial smooth surface, and later the same is polished with 600 Grid sandpaper to get a fine and glassy surface. Figure-3 shows the sectional image of coconut shell concrete of $100 \mathrm{~mm} \times 100 \mathrm{~mm}$ size. The core cutting machine is used to cut the specimen of $10 \mathrm{~mm} \times 10$ $\mathrm{mm}$ size. Figure-4 represents the glassy finish of coconut shell concrete after been rubbed from 600 grid salt paper.

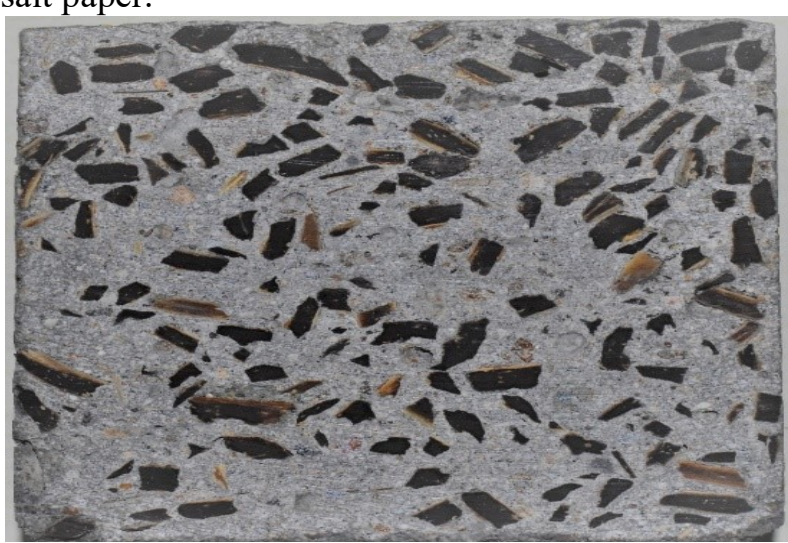

Fig.-3: Sectional Image of CSC

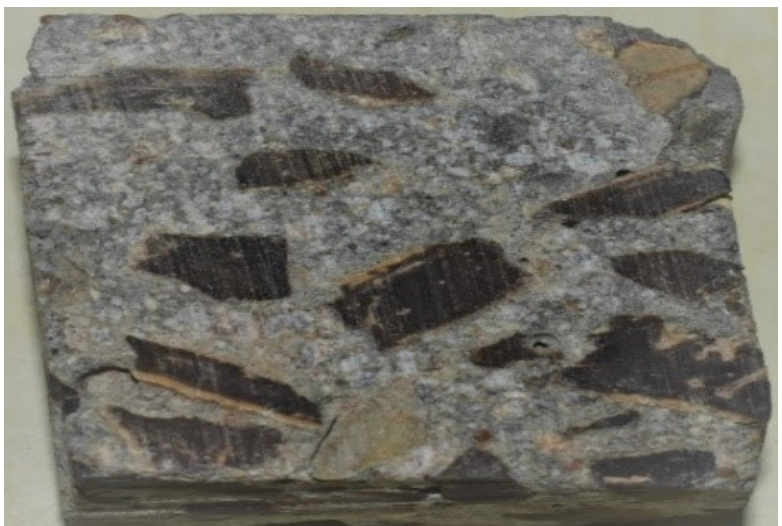

Fig.-4: Polished Image of CSC Table-7: Impact Resistance of CC and CSC at $28^{\text {th }}$ Day

\begin{tabular}{c|c|c|c}
\hline \multirow{2}{*}{ Mix Proportion } & \multirow{2}{*}{ Compressive Strength in N/mm } & \multicolumn{2}{|c}{ The average number of Blows } \\
\cline { 3 - 4 } & & Initial Crack & Crack at Failure \\
\hline AC1 & 31.2 & 12 & 20 \\
\hline AC5 & 30.3 & 15 & 24 \\
\hline ACS7 & 26.4 & 21 & 29 \\
\hline ACS11 & 25.1 & 21 & 28 \\
\hline
\end{tabular}


RASĀYAN J. Chem.

Vol. 12 | No. 4 |2218 - 2226| October - December | 2019

The polished specimen is placed in IMM to study the ITZ between coarse aggregate (CA) - cement mortar (CM) - coconut shells (CS) and bond width (BW). The microscopic test was conducted for the age 3,7 and $28^{\text {th }}$ days of curing. The test was carried at a range of $100 \mathrm{x} \mathrm{zoom} .{ }^{19}$ From the test results it shows that the $\mathrm{BW}$ between $\mathrm{CA}-\mathrm{CM}-\mathrm{CS}$ is reducing for the age 3, 7 and 28 respectively. The figure below shows the bond with the mentioned samples.

The red line indicates the measurement taken for the entire BW between aggregate and mortar. The IMM calculates the value automatically and delivers the value in three forms say maximum, minimum and average value. The table below shows the values of IMM results of conventional concrete. Figure-5 indicates the $3^{\text {rd }}$ day image of conventional concrete having the bond layer thickness between CC and mortar. The red line on the image indicates the entire measurement of bond width between aggregate and mortar. The maximum and minimum value was found to be 442.84 and 243.17 micrometers. The average value of the same is automatically derived from the IMM by considering the maximum and minimum of the entire surface taken for the measurement, and the average of $3^{\text {rd }}$ day curing period is 294.15 micrometer. The same principle is followed for measuring $7^{\text {th }}$ and $28^{\text {th }}$ days. The Fig.- 6 and 7 shows the image of $7^{\text {th }}$ and $28^{\text {th }}$ day of curing period, these images in visual represents the decrease in the thickness of bond layer with increase in curing period. By calculating the maximum and minimum value for the above days, the average value is said to be 239.91 and 161.32 micrometer. The decrease in value clearly represents the increase in bonding layer as the age increases. In the same way the IMM analysis that conducted for CSC shows the maximum value of $267.6,195.05$ and 139.94 micrometer for $3^{\text {rd }}, 7^{\text {th }}$ and $28^{\text {th }}$ day. The minimum value for the same is $123.98,95.77$ and 85.73 . The average value for the coconut shell concrete decreases from 175.65 to 112.09 for $3^{\text {rd }}$ day to $28^{\text {th }}$ day. The figure 8,9 and 10 represents the IMM image of CSC of $3^{\text {rd }}, 7^{\text {th }}$ and $28^{\text {th }}$ day curing period. Figure- 11 and 12 represent the IMM values for both the concrete.

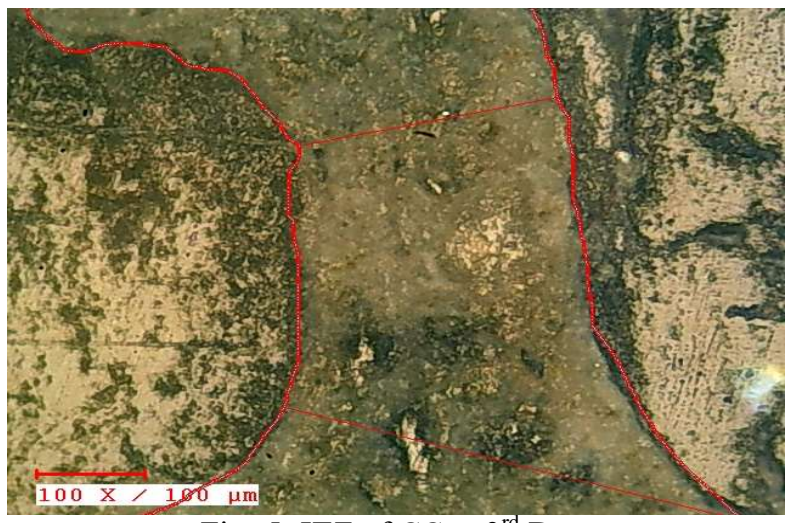

Fig.-5: ITZ of CC at $3^{\text {rd }}$ Day

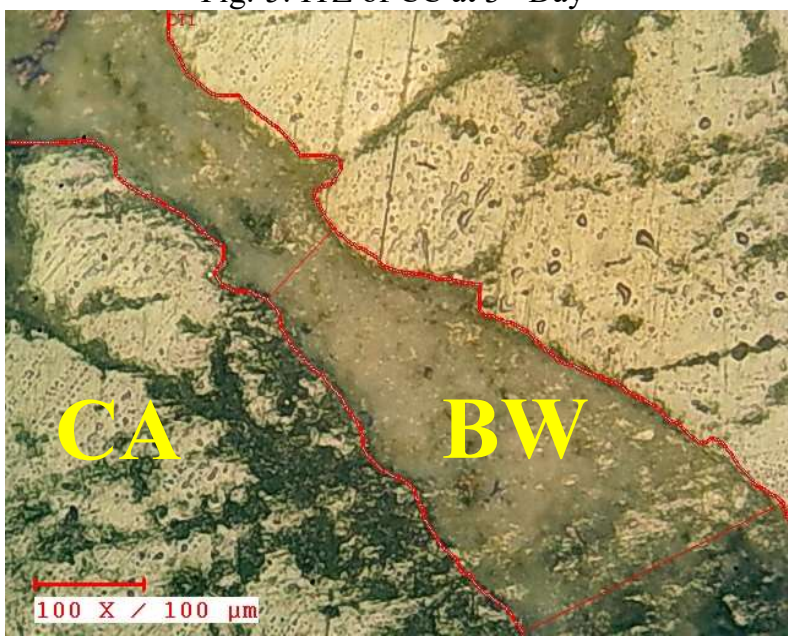

Fig.-7: ITZ of CC at $7^{\text {th }}$ Day

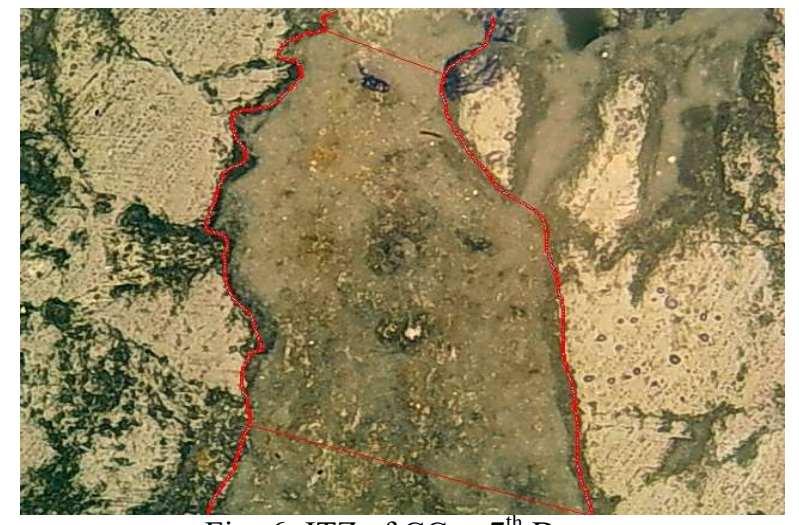

Fig.-6: ITZ of CC at $7^{\text {th }}$ Day

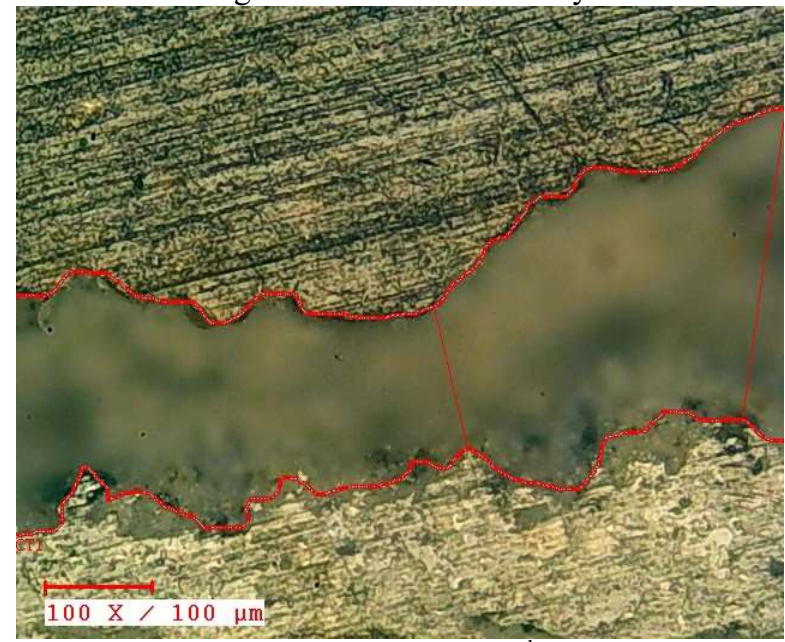

Fig.-8: ITZ of CSC at $3^{\text {rd }}$ Day 
RASĀYAN J. Chem.

Vol. 12 | No. 4 |2218 - 2226| October - December | 2019

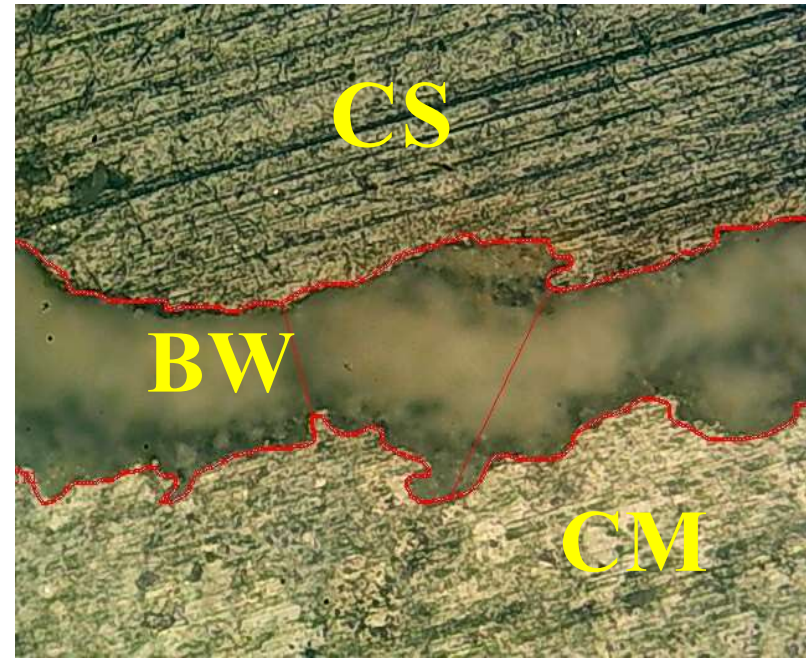

Fig.-9: ITZ of CSC at $7^{\text {th }}$ Day

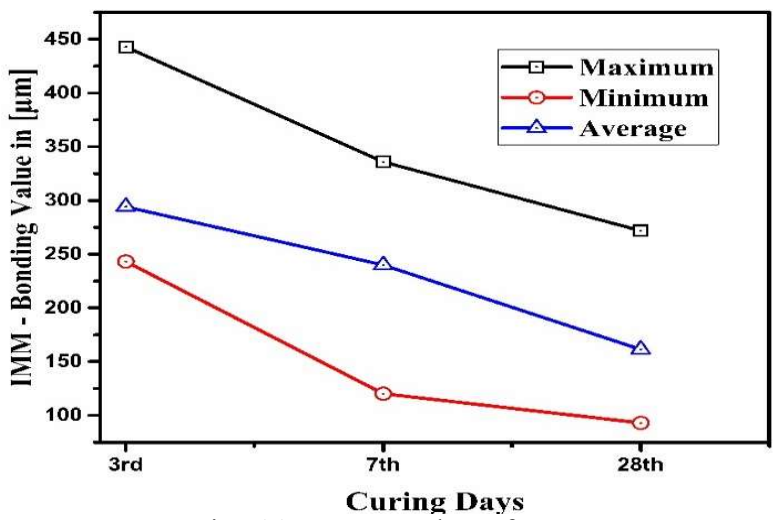

Fig.-11: IMM Value of CC

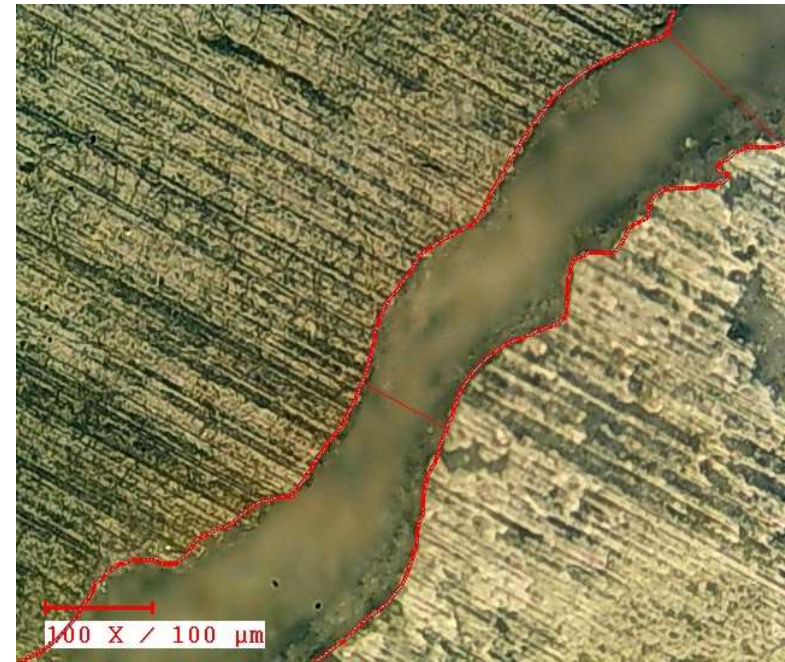

Fig.-10: ITZ of CSC at $7^{\text {th }}$ Day

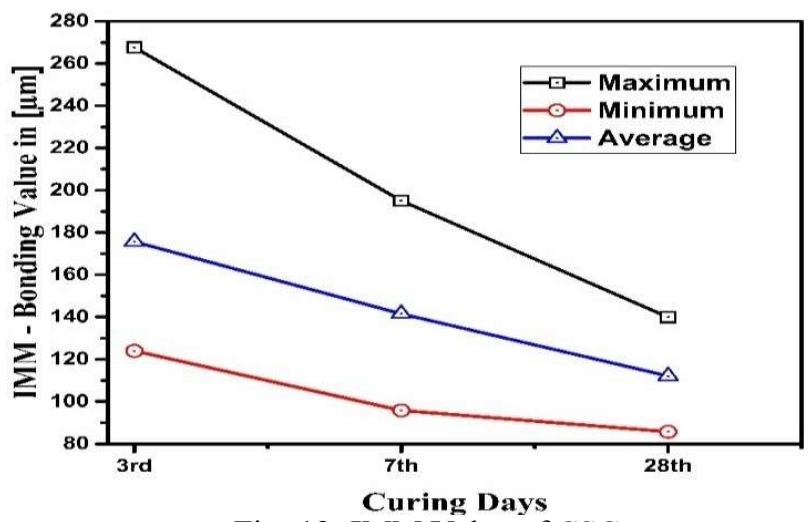

Fig.-12: IMM Value of CSC

The above graph clearly shows that the bond between the aggregate and mortar decreases as the age increases.

\section{CONCLUSION}

From the study, the compressive strength was conducted for complete one year, in which the strength is increasing from $3^{\text {rd }}$ day to $365^{\text {th }}$ day. From the results of CSC, at $10 \%$ alccofine has the maximum strength of about $11.7 \%$ higher to $100 \%$ OPC, and from the overall replacement, it is found the optimum replacement of cement with alccofine is $20 \%$ which achieves the targeted mean strength of the concrete. Ultra-sonic pulse velocity test shows both the concrete are good, which confirms the CSC can be used for all kinds of structural works. As per IS 456:2000 ${ }^{32}$, the flexural strength values are almost equal while comparing with compressive strength results. Both CC and CSC shows similar kind of result in split tensile strength. The impact resistance of CSC is 55\% higher comparing with CC at $100 \%$ cement and similarly $37.5 \%$ higher at $20 \%$ alccofine, at the same time the impact resistance of CSC at $20 \%$ alccofine is $6.45 \%$ higher than at $100 \%$ cement, this is because of fiber present on CS and effect of alccofine, which has more silica content. The IMM analysis indicated the bond width layer decreases with increase in curing period. The CS has higher bonding with mortar while comparing to coarse aggregate, this could be due to the shape of the coconut shell, which is flaky. Comparing to CC the CSC has 2.5 times higher bonding value.

\section{REFERENCES}

1. E. F. Rajaonarison, A. Gacoin, R. Randrianja, V. G. Ranaivoniarivo, and B. H. N. Razafindrabe, Int. J. Concr. Struct. Mater,11(3), 541(2017).

2. D. S. Law Yim Wan, F. Aslani, and G. Ma, 30(8), 04018178(2018), DOI: 10.1061/(ASCE)MT.1943- 
RASĀYAN J. Chem.

Vol. 12 | No. 4 |2218 - 2226| October - December | 2019

5533.0002350 .

3. F. Aslani, G. Ma, D. L. Yim Wan, and G. Muselin, J. Clean. Prod., 182, 553(2018), DOI: 10.1016/j.jclepro.2018.02.074.

4. H. Fashandi, H. R. Pakravan, and M. Latifi, Constr. Build. Mater, 198, 629(2019), DOI: 10.1016/j.conbuildmat.2018.11.163.

5. M. Aslam, P. Shafigh, and M. Z. Jumaat, KSCE J. Civ. Eng, 22(12), 4997(2018), DOI: 10.1007/s12205-017-0630-x.

6. K. Gunasekaran, S. Praksah Chandar, R. Annadurai, and K. S. Satyanarayanan, Eur. J. Environ. Civ. Eng., 21(5),629(2017), DOI:10.1080/19648189.2016.1144540.

7. K. Gunasekaran, R. Annadurai, and P. S. Kumar, Mater. Struct. Constr, 48(5), 1253(2015), DOI: 10.1617/s11527-013-0230-2.

8. K. Gunasekaran, R. Ramasubramani, R. Annadurai, and S. Prakash Chandar, Mater. Des., 57, 374(2014), DOI:10.1016/j.matdes.2013.12.058.

9. Gunasekaran, R. Annadurai, and P. S. Kumar, Constr. Build. Mater, 43, 203(2013), DOI: 10.1016/j.conbuildmat.2013.02.019.

10. K. Gunasekaran, R. Annadurai, and P. S. Kumar, Mater. Des, 50, 293(2013), DOI:10.1016/j.matdes.2012.09.044.

11. K. Gunasekaran, R. Annadurai, and P. S. Kumar, Constr. Build. Mater., 28(1), 208(2012), DOI: 10.1016/j.conbuildmat.2011.08.072.

12. V.R.Prasath Kumar, K. Gunasekaran, Rasayan J. Chem, 12(3), 1575(2019), DOI: $10.31788 /$ RJC.2019.1235251

13. S. Prakash Chandar, K. Gunasekaran, K. S. Satyanarayanan, and R. Annadurai, Eur. J. Environ. Civ. Eng., 8189, 1(2018), DOI:10.1080/19648189.2017.1418435.

14. Y. Nadir and A. Sujatha, Asian J. Civ. Eng., 19(6), 713(2018), DOI:10.1007/s42107-018-0060-1.

15. V.R.Prasath Kumar, K. Gunasekaran, Journal of Building Engineering, 26, 1(2019), DOI: $10.1016 /$ j.jobe.2019.100830

16. S. Gupta, S. Sharma, and E. D. Sharma, Int. J. Mod. Trends Eng. Res., 2(8), 114(2015).

17. S. K. Saxena, M. Kumar, and N. B. Singh, Med. Monatsschr. Pharm., 19(8), 237(1996).

18. Parveen, D. Singhal, M. T. Junaid, B. B. Jindal, and A. Mehta, Constr. Build. Mater., 180, 298(2018).

19. A. R. B. Reddy and A. Rajeswari, Int. Conf. Electr. Electron. Optim. Tech., 2(6), 2240(2016).

20. S. P. Upadhyay, Int. J. Innov. Res. Dev., 3(2), 124(2014).

21. P. J. Patel and H. S. Patel, Int. J. Civil, Struct. Environ. Infrastruct. Eng. Res. Dev., 3(2), 109(2013).

22. M. Santhosh Kumar, V. R. Prasath Kumar, and K. Gunasekaran, Int. J. Chem. Sci., 14, 247(2016)

23. Y. M. Shivaprakash, H. C. Ramu, Chiranjivee, R. Kumar, and D. Kumar, IOP Conf. Ser. Mater. Sci. Eng., 310(1), 1(2018).

24. N. Radhika, Tribol. Ind., 39(1), 1(2017).

25. L. Krishnaraj, R. S. Lakshmi, and P. T. Ravichandran, Rasayan J. Chem, 10(2), 592(2017), DOI: $10.7324 /$ RJC.2017.1021670

26. S. P. Chandar, K. Gunasekaran, K. Prasanth, and G. S. Kumar, Rasayan J. Chem, 11(2), 702( 2018), DOI: 10.31788/RJC.2018.1123003

27. D. Dutta and S. Ghosh, Rasayan J. Chem, 11(3), 1018 (2018), DOI: 10.31788/RJC.2018.1133046

28. IS. 383:1970, IS.383.1970.

29. IS 516:1959, Method of Tests for Strength of Concrete.

30. IS:5816-1999, Splitting tensile strength of concrete, 2004.

31. IS 13311:1992, Non-Destructive Testing of Concrete - Methods of Test.

32. IS 456:2000, Plain and Reinforced Concrete - Code of Practice.

[RJC-5231/2019] 